\title{
ENQUETE
}

\section{Om „Samlingen“ som genre}

Samlingen har - ligesom de ting der udfylder den - en typisk livshistorie, en begyndelse og en slutning. Ser man på Nationalmuseets Etnografiske Samling i historisk perspektiv, så har den sine aner i Det kongelige Kunstkammer, der oprettedes i 1600-tallet som et „Rarietetskabinet“. Dengang bestod samlingen af alverdens mærkværdigheder, misfostre, naturhistoriske sjældenheder og etnografika foruden malerier ikke mindst af de vilde. Den var aldeles uden systematik, kronologi, regionalisering og det eneste udvælgelseskriterium var kongen, Frederiks III's subjektive smag for det ekstraordinære. Her taler vi om den private samling, den som hver anden af os genkender fra barndommens land, hvor et ferieophold fik os til at samle på muslingeskaller, fugleæg eller frimærker. Den personlige interesse og subjektive kriterier er grundelementerne i den private samling, og som sådan er den grænseløs.

Imidlertid bliver en samling sjældent ret gammel, førend samleren fristes til at vise den frem. Ved at gå fra den private og hemmelige samling til den offentligt tilgængelige, fra skattekisten til hylden eller museumsmontren, sker der radikale forandringer. Igen kan det sidestilles med den udvikling, der fandt sted ved enevældets ophør, hvor kongens privatsamling blev statens eje og eksponeredes for et borgerligt publikum. Når en samling udstilles - bliver offentlig - antager den intersubjektiv betydning på vejen mod en egentlig intentionalitet. Den bliver sammenlignelig med andre tilsvarende samlinger, og samleren antager også rollen som kurator og begynder at anlægge alment acceptable kriterier for samlingens begrænsninger, systematik og kvalitet.

Der sker intet mindre end et paradigmekollaps, når samlingen går fra privat til offentligt regi. I sit udspring er samlingens enkelte genstande subjektivt udvalgt og illustrerer hyppigt samlerens identitet igennem det, han finder ekstraordinært, mens den offentlige samling successivt opbygges over genstandenes indbyrdes relation, altså objektive kriterier, der forholder sig til den ordinære verden. Samlingens enkelte genstande blive dog i en vis forstand ved med at være ekstraordinære, nemlig i kraft af at være rykket ud af deres oprindelige kontekst. Så mærkeligt det end kan lyde, så opleves tingene netop som autentiske, fordi de er fjernet fra deres naturlige sammenhæng, og som en slags gesandter optræder i en ny rolle i for eksempel museets udstilling. Og - lige så vigtigt - det er samme forhold, der gør alle tingene - også de naturhistoriske - til kulturelle produkter, underkastede et eller andet menneskeskabt klassifikationssystem.

Det hænger sammen med at tingene, nu adskilte fra deres oprindelige, naturlige kontekst, drages ind i en ny, kunstig kontekst, nemlig „Samlingen“. Gåseøjnene henviser til at samlingen er omgivet af en usynlig ramme, ligesom en parentes i en tekst, der fortæller at tekstens indhold er underkastet specielle betingelser, at der for eksempel er tale om forfatterens private kommentar eller en digression til et andet regi.

En samlings ramme indeholder altid en appel, en appel om at blive godtaget som noget uden for dagliglivet. Den sten $ø$ kse, der ligger i en arkæologisk samling bag glas, og som end ikke må berøres, er langt fra den samme $\emptyset \mathrm{kse}$, vore forfædre ryddede skovene 
med, den har mistet sin nytteværdi, den der lå i den oprindelige kontekst, og er blevet en skueret, der nu vurderes for eksempel æstetisk eller teknologisk-typologisk. Ikke denne ting, men den slags ting, brugte man dengang; det er tingens autenticitet, at den optræder som metafor for en hel fortidskultur. Det er i det hele taget karakteristisk, at samlingen består af eksemplarer frem for tilfældige ophobninger; derfor følges en samling ofte af en „dubletsamling“, der har som formål at fjerne gentagelser og tvivlsom kvalitet fra selve „Samlingen“, således at denne kan stå med uantastet autoritet.

Samlingens ramme er som en kommentar til publikum: „Her skal I bare se! Disse ting er ikke, hvad de umiddelbart giver sig ud for“. På samme måde som Magritte på sit billede af en pibe skrev: dette er ikke en pibe, så er $\varnothing$ ksen jo heller ikke en $\varnothing \mathrm{kse}$ til at tage op og fælde træer med, men en indrammet $\emptyset$ kse. Virkningen kan yderligere forstærkes ved, hvad man kunne kalde klenodieeffekten, hvor en særlig fremragende genstand i samlingen tildeles stjernestatus og får sin egen ekstra indramning i form af spærringer og tyverialarmer. Det kendes især fra malerisamlinger og tænkes at kaste glans også over resten af kollektionen; men det er samtidig med til at nedbryde udstillingen som samling.

For nu til slut at gå tilbage til samlingen som livsforløb, må man spørge, hvornår en samling ophører med at være en „Samling“. Det bliver et spørgsmål om definitioner. Når samlingen bliver offentlig og institutionaliseret og blandes med andre samlinger på et museum, fortoner det subjektive udvælgelsesprincip sig, og professionelle kuratorer tager ansvaret fra indsamleren.

Måske kan man skelne mellem primære og sekundære samlinger, hvor de sekundære faktisk er samlinger af samlinger, der efterhånden mister deres individuelle præg. Etnografisk Samling på Nationalmuseet er et tydeligt eksempel herpå, hvor man stadig kan opleve en genuin „Samling“, nemlig Knud Rasmussens store eskimosamling, der afspejler indsamlerens subjektive interesse. Knud Rasmussen udgav også for eksempel eskimoiske myter og sagn i den personlige samlings form. Hovedparten af Etnografisk Samling har imidlertid været udsat for professionelle kuratorers fragmentering og æstetisering og fortjener næppe ordet „Samling“ længere.

I en snæver forstand er en samling altså en genre, hvis charme beror på, at en del af verden, et semantisk domæne er set og udvalgt igennem et personligt temperament, med de blinde pletter, som det medfører. Samlinger har det med at gå til grunde i professio-nalismens tidsalder, men for $\emptyset$ vrigt også under en post-modernistisk påvirkning som den, der ramte museerne i 1980-90-erne, og som præcis gjorde en dyd af det fragmenterede, multivokale og ucentrerede udtryk. Det var at gå stik imod „Samlingens“ ide, ja i nogle tilfælde ligefrem at gå ,fra sans og samling“.

Niels Fock, antropolog 